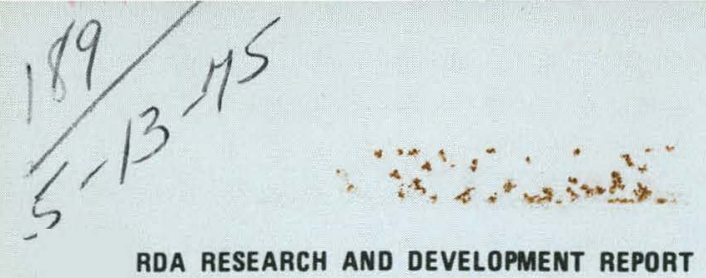

RDA RESEARCH AND DEVELOPMENT REPORT
K-1872

Rev. 1

\title{
EVALUATION OF A OUADRUPOLE MASS SPECTROMETER FOR THE ISOTOPIC ANALYSIS OF URANIUM HEXAFLUORIDE
}

H. C. Jones

MARCH 1975

\section{OAK RIDGE GASEOUS DIFFUSION PLANT} OAK RIDGE. TENNESSEE 


\section{DISCLAIMER}

This report was prepared as an account of work sponsored by an agency of the United States Government. Neither the United States Government nor any agency Thereof, nor any of their employees, makes any warranty, express or implied, or assumes any legal liability or responsibility for the accuracy, completeness, or usefulness of any information, apparatus, product, or process disclosed, or represents that its use would not infringe privately owned rights. Reference herein to any specific commercial product, process, or service by trade name, trademark, manufacturer, or otherwise does not necessarily constitute or imply its endorsement, recommendation, or favoring by the United States Government or any agency thereof. The views and opinions of authors expressed herein do not necessarily state or reflect those of the United States Government or any agency thereof. 


\section{DISCLAIMER}

Portions of this document may be illegible in electronic image products. Images are produced from the best available original document. 
Printed in the United States of America. Available from National Technical Information Service

U.S. Department of Commerce

5285 Port Royal Road, Springfield, Virginia 22161

Price: Printed Copy $\$ 4.00$; Microfiche $\$ 2.25$

This report was prepared as an account of work sponsored by the United States Government. Neither the United States nor the Energy Research and Development Administration, nor any of their employees, nor any of their contractors, subcontractors, or their employees, makes any warranty, express or implied, or assumes any legal liability or responsibility for the accuracy, completeness or usefulness of any information, apparatus, product or process disclosed, or represents that its use would not infringe privately owned rights. 
Digest of

Report K-1872,

Rev. 1

EVALUATION OF A QUADRUPOLE MASS SPECTROMETER

FOR THE ISOTOPIC ANALYSIS OF URANIUM HEXAFLUORIDE

H. C. Jones

Isotopic Analysis Department

Laboratory Division

Report Date: March 1975

Report Classification: UNCLASSIFIED

A quadrupole mass spectrometer was examined for adaptation to the onstream isotopic analysis of uranium hexafluoride (UF 6 ) in gaseous diffusion cascades. Source modifications, in conjunction with a molecular beam type inlet system and a liquid nitrogen cold trap, made the quadrupole reasonably compatible with $\mathrm{UF}_{6}$ at analyzer pressures of not more than 10-8 torr. Uranium-235/uranium-238 ratios were measured using automatic peak-switching and integrating circuitry. These measurements indicated that the apparent high resolution of the quadrupole could not be realized with $\mathrm{UF}_{6}$, due to inadequate sensitivity and low signal-tonoise ratio. After extensive examination of the system, it was concluded that further efforts to adapt the quadrupole to isotopic analysis of $\mathrm{UF}_{6}$ would be impractical at this stage in quadrupole development.

This report contains 9 pages, including 3 tables and 1 reference.

Oak Rịdge Gaseous Diffusion Plant

Union Carbide Corporation

Oak Ridge, Tennessee

Prepared for the U. S. Energy Research and Development Administration under U. S. Government Contract W-7405 eng 26 
H. C. Jones

Isotopic Analysis Department

Laboratory Division

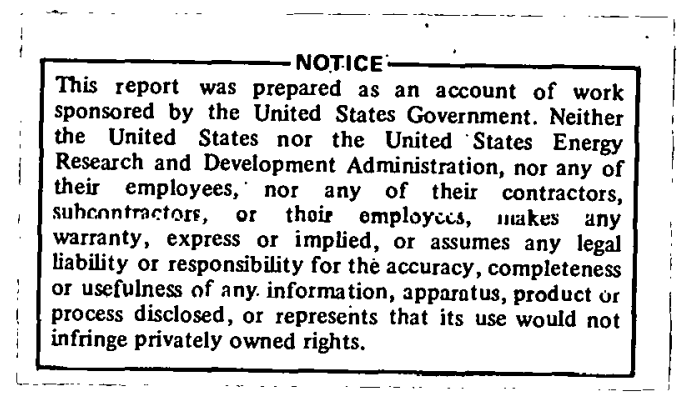

\footnotetext{
Oak Ridge Gaseous Diffusion Plant Union Carbide Corporation Oak Ridge, Tennessee
}

Prepared for the U. S. Energy Kesearch and Development Administration under U. S. Government Contract W-7405 eng 26 
ABSTRACT

A quadrupole mass spectrometer was examined for adaptation to the onstream isotopic analysis of uranium hexafluoride $\left(\mathrm{UF}_{6}\right)$ in gaseous diffusion cascades. Source modifications, in conjunction with a molecular beam type inlet system and a liquid nitrogen cold trap, made the quadrupole reasonably compatible with $\mathrm{UF}_{6}$ at analyzer pressures of not more than $10^{-8}$ torr. Uranium-235/uranium-238 ratios were measured using. automatic peak-switching and integrating circuitry. These measurements indicated that the apparent high resolution of the quadrupole could not be realized with $\mathrm{UF}_{6}$, due to inadequate sensitivity and low signal-tonoise ratio. After extensive examination of the system, it was concluded that further efforts to adapt the quadrupole to isotopic analysis of $\mathrm{UF}_{6}$ would be impractical at this stage in quadrupole development. 
CONTENTS

Page

INTRODUCTION . . . . . . . . . . . . . . . . . . 4

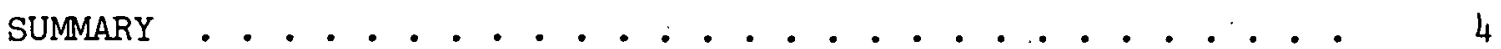

INSTRUMENT MODIFICATION AND EVALUATION . . .......... 4

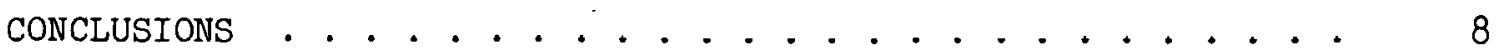




\author{
EVALUATION OF A QUADRUPOLE MASS SPECTROMETER \\ FOR THE ISOTOPIC ANALYSIS OF URANIUM HEXAFLUORIDE
}

\title{
INTRODUCTION
}

The quadrupole mass spectrometer appeared to offer attractive possibilities for isotopic monitoring of uranium hexafluoride $\left(\mathrm{UF}_{6}\right)$ for several reasons. The quadrupole is basically a high-resolution, fast-scanning, portable instrument which is commercially available. The object of this investigation was to determine whether the quadrupole could be made compatible with the highly corrosive and intractable $\mathrm{UF}_{6}$, and whether uranium-235/ uranium-238 ratio measurements having the desired precision could be obtained with a quadrupole system.

\section{SUMMARY}

In the investigation of the quadrupole mass spectrometer as a monitor of isotopic concentration of $\mathrm{UF}_{6}$, the original commercial instrument (Finnigan Instruments Corporation Model 1015*) was modified to make it reasonably compatible with $\mathrm{UF}_{6}$ and automatic peak-switching circuitry was attached to the quadrupole to permit uranium-235/uranium-238 ratio measurements. The relative standard deviation of these measurements, and measurements made later using a replacement RF-DC power supply (from Extranuclear Laboratories*), was about $\pm 1 \%$. The use of automatic signal integration circuitry and digital readout eliminated measuring circuitry as a significant contributor to poor precision, but did not result in acceptable measurement precision. At this stage in quadrupole development, it was thus concluded that further investigation of the quadrupole for on-stream isotopic analysis of $\mathrm{UF}_{6}$ could not be justified.

\section{INSTRUMENT MODIFICATION AND EVALUATION}

The quadrupole, as received, was equipped with Monel filter rods and a nichrome source. The source structure was modified to minimize contact between $\mathrm{UF}_{6}$ and the ionization chamber. Both sides of the conventional source structure were removed, the electron trap size was reduced, and the top was cantilevered from the filament side. The rhenium ribbon filament was replaced with a $0.18-\mathrm{mm}$ tungsten wire and the filament support was strengthened to prevent the filament from sagging out of position. A molecular beam nozzle ( $1-\mathrm{mm}-\mathrm{ID}$ Pyrex tube about $25 \mathrm{~mm}$ long sealed in the end of a copper tube with Apiezon $W$ black wax) and a cold trap were installed on opposite sides of the open source. At a later time, the source exit aperture was enlarged slightly and an external source magnet was installed to increase the sensitivity of the instrument.

*Reference to a Company or Product name does not imply approval or recommendation of the product by Union Carbide Corporation or the United States Energy Research and Development Administration to the exclusion of others that may meet specifications. 
Initial source life of the quadrupole, during exposure to $\mathrm{UF}_{6}$, was limited to a few hours whenever it was necessary to operate the analyzer at pressures above $10^{-8}$ torr. By careful optimization of all controllable parameters (ionizing electron energy and current, ion lens potential, ion energy, source magnet position, and resolution control), analyzer pressure was held below $10^{-8}$ torr and source life was extended to approximately $300 \mathrm{hr}$.

Automatic peak-switching circuitry was installed on the quadrupole and uranium-235/uranium-238 ratio measurements were made using a manually balanced ratiometer. The precision of these measurements, as indicated in Table 1, was not satisfactory, even though the measurements did not reflect the maximum fluctuations present in the ratio. It was not possible to balance the ratiometer on these rapid fluctuations. Other measurements were made using the replacement RF-DC control unit and the same measuring circuitry. The precision of these measurements, Table 1, showed no improvement. Automatic timing and integrating circuitry, with digital ratiometer readout, was installed to eliminate errors inherent in the manual observations. Subsequent measurements show an improvement in shortterm precision, Table 2, but no improvement in long-term precision is indicated when the measurements in Table 2 are combined to give the results shown in Table 3. Individual observations were made at 10-sec intervals to produce the results in Table 2. These observations were averaged at 50-sec intervals to give the longer-term precision figure in Table 3.

Table 1

ISOTOPIC ANALYSIS OF URANIUM HEXAFLUORIDE WITH QUADRUPOLE, AUTOMATIC PEAK-SWITCHING WITH MANUAL RATIO MEASUREMENT

\begin{tabular}{lcccc}
\hline & \multicolumn{2}{c}{ Original RF-DC Control } & & \multicolumn{2}{c}{ Replacement RF-DC Control } \\
\cline { 2 - 3 } Date & $9-30-71$ & $9-30-71$ & $8-15-73$ & $8-20-73$ \\
$\begin{array}{l}\text { True Wt \% } \\
\text { Uranium-235 }\end{array}$ & 3.4995 & 2.6984 & 4.0615 & 3.3358 \\
$\mathrm{~N}$ & 25 & 25 & 46 & 46 \\
$\overline{\mathrm{X}}$ & 3.424 & 2.700 & 4.0730 & 3.36 \\
$\mathrm{~S}_{\mathrm{X}}$ & \pm 0.0383 & \pm 0.0227 & \pm 0.039 & \pm 0.0373 \\
$\%$ S & \pm 1.12 & \pm 0.84 & \pm 0.97 & \pm 1.11 \\
Bias & -0.0755 & +0.0016 & +0.012 & +0.02 \\
$\%$ Bias & -2.16 & +0.11 & +0.29 & +0.60 \\
\hline
\end{tabular}


Table 2

ISCTOPIC ANALYSIS OF URANIUM HEXAFLUORIDE WITH

QUADRUFOLE, AUTOMATII PEAK-SWITCHING AND INTEGRATION,

DIGITAL RATIOMETER READOUT, REPLACEMENT RF-DC CONTROI

\begin{tabular}{|c|c|c|c|c|c|c|c|c|}
\hline Set & $\mathrm{Al}$ & A2 & $\mathrm{BI}$ & $\mathrm{B} 2$ & $\mathrm{Cl}$ & $\mathrm{C} 2$ & $\mathrm{Dl}$ & D2 \\
\hline Date & $2-1-74$ & $2-1-74$ & $2-1-74$ & $2-1-74$ & $2-1-74$ & $2-1-74$ & $2-1-74$ & $2-1-74$ \\
\hline $\begin{array}{l}\text { True Wt \% } \\
\text { JJranium-235 }\end{array}$ & 3.3358 & 3.3358 & 3.3358 & 3.3358 & 3.3358 & 3.3358 & 3.3358 & 3.3358 \\
\hline $\mathbb{N}$ & 25. & 25 & 25 & 25 & 25 & 25 & 25 & 25 \\
\hline $\overrightarrow{\mathrm{X}}$ & 3.2098 & 3.1870 & $3.251+2$ & 3.2376 & 3.1481 & 3.1371 & 3.2358 & 3.2053 \\
\hline $\mathrm{S}_{\mathrm{X}}$ & \pm 0.022 & \pm 0.017 & \pm 0.015 & \pm 0.015 & \pm 0.013 & \pm 0.009 & \pm 0.015 & \pm 0.011 \\
\hline$\% \mathrm{~s}_{\mathrm{x}}$ & \pm 0.69 & \pm 0.54 & \pm 0.47 & \pm 0.48 & \pm 0.40 & \pm 0.28 & \pm 0.45 & \pm 0.35 \\
\hline Bias & -0.1261 & -0.1488 & -0.0816 & -0.0982 & -0.1877 & -0.1987 & -0.1000 & -0.1305 \\
\hline$\%$ 3ias & -3.78 & -4.46 & -2.45 & -2.94 & -5.63 & -5.96 & -3.00 & -3.91 \\
\hline$S \equiv t$ & E1 & E2 & E3 & & & & & \\
\hline Date & $2-1-74$ & $2-1-74$ & $2-1-74$ & & & & & \\
\hline $\begin{array}{l}\text { True wt \% } \\
\text { Jranium-235 }\end{array}$ & 3.3358 & 3.3358 & 3.3358 & & & & & \\
\hline$N$ & 25 & 25 & 25 & & & & & \\
\hline$\overline{\mathrm{X}}$ & 3.1160 & 3.1274 & 3.1184 & & & & & \\
\hline $\mathrm{S}_{\mathrm{X}}$ & \pm 0.011 & \pm 0.012 & \pm 0.011 & & & & & \\
\hline$\% \mathrm{~s}_{\mathrm{X}}$ & \pm 0.35 & \pm 0.39 & \pm 0.35 & & & & & \\
\hline Bias & -0.2178 & -0.2084 & -0.2174 & & & & & \\
\hline$\%$ Bias & -6.53 & -6.25 & -6.52 & & & & & \\
\hline
\end{tabular}


Table 3

ISOTOPIC ANALYSIS OF URANIUM HEXAFLUORIDE WITH QUADRUPOLE, AUTOMATIC PEAK-SWITCHING AND INTEGRATION, DIGITAL RATIOMETER READOUT, REPLACEMENT RF-DC CONTROL

Observations reported in Table 2 averaged at $50-\mathrm{sec}$ intervals to give one set of 55 observations

$\begin{array}{lc}\text { Date } & 2-1-74 \\ \text { True Wt \% Uranium-235 } & 3.3358 \\ \mathrm{~N} & 55 \\ \overline{\mathrm{X}} & 3.3262 \\ \mathrm{~S}_{\mathrm{X}} & 0.05265 \\ \% \mathrm{~S}_{\mathrm{X}} & 1.6559 \\ \text { Bias } & -0.1561 \\ \% \text { Bias } & -4.68\end{array}$

Although encouraging data were obtained after extensive quadrupole modifications, performance was still short of that required for the intended application. It was thus necessary to review the overall status of the instrument before planning other approaches.

Operation of the quadrupole with $\mathrm{UF}_{6}$ requires repeated adjustment of several parameters (electron current, electron energy, ion lens potential, ion energy, source magnet position, resolution control, pole bias, and $\Delta \mathrm{m}$ control) in order to maintain maximum sensitivity and desired resolution (complete separation of the ${ }^{235} \mathrm{UF}_{5}$ and ${ }^{238} \mathrm{UF}_{5}$ peaks at 330 and 333 amu, respectively, as observed on an oscilloscope). Maximum sensitivity is necessary to minimize the rate of formation of $\mathrm{UF}_{6}$ reaction products on the ion source, but at pressures $>10^{-8}$ torr, in the main body of the analyzer, these deposits are formed very rapidly. Reproducibility of desired conditions from day to day is unsatisfactory. The extremely low ion acceleration potential necessary to obtain adequate resolution results in poor ion extraction efficiency and thus low sensitivity with $\mathrm{UF}_{6}$. Ion peak splitting* also contributes to the overall noise observed, and is

*Whetten, N. R. and Dawson, P. H., Some Causes of Poor Peak Shapes in Quadrupole Field Mass Analyzers, Electron Physics Laboratory, General Electric Research and Development Center, Schenectady, New York, September 1968 (Report No. 68-6-3lI). 
difficult to control because of surface conditions on the filter poles. Signal-to-noise ratio and precision of measurement are thus limited to unacceptable values.

\section{CONCLUSTONS}

Operation of the quadrupole for the isotopic analysis of $\mathrm{UF}_{6}$ was found to be very difficult. Under the best operating conditions attained, source life was limited to approximately $300 \mathrm{hr}$. Measurement precision obtained with the quadrupole under these conditions was still an order of magnitude from that needed for an on-stream isotopic monitor.

In view of the numerous parameters which need better control, it was, therefore, concluded that the quadrupole, at its present state of development, is not suitable for the isotopic analysis of $\mathrm{UF}_{6}$. Further quadrupole development for stream monitor application should thus be diverted to other types of mass spectrometry. 
INTERNAL

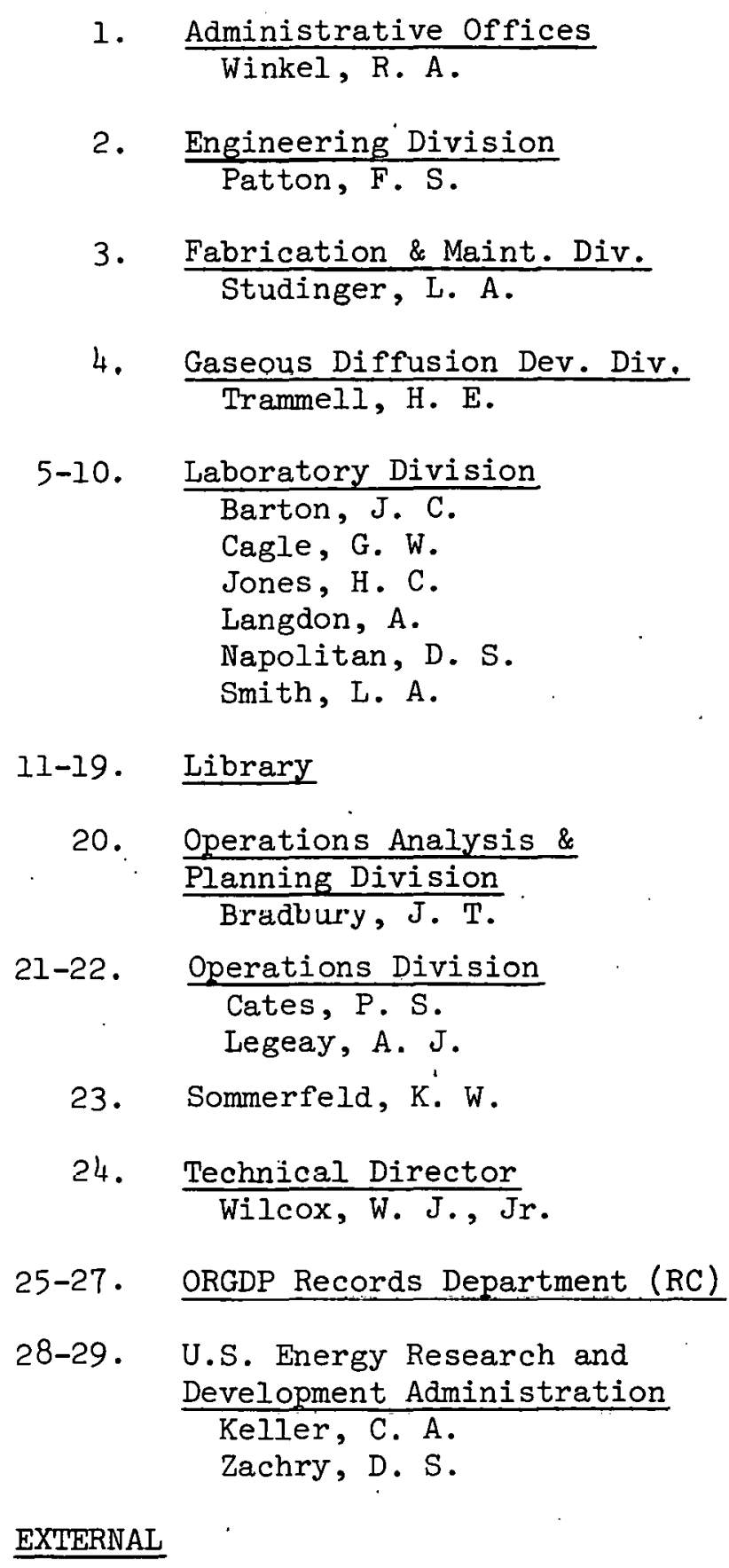

1. Administrative Offices Winkel, R. A.

2. Engineering Division Patton, F. S.

3. Fabrication \& Maint. Div. Studinger, L. A.

4. Gaseous Diffusion Dev. Div.

5-10. Laboratory Division Barton, J. C. Cagle, G. W. Jones, H. C. Langdon, A. Napolitan, D. S. Smith, L. A.

11-19. Library

20. Operations Analysis \&

Planning Division Bradbury, J. T.

21-22. Operations Division Cates, P. S. Legeay, A. J.

23. Sommerfeld, K'. W.

24. Technical Director Wilcox, W. J., Jr.

25-27. ORGDP Records Department (RC)

28-29. U.S. Energy Research and Development Administration Keller, C. A. Zachry, D. S.

EXTERNAL

39-227. TID-4500
30. Goodyear Atomic Corporation Voss, F. S.

31-32. Paducah Plant Hopkins, C. C. Levin, R. W.

33-38. Y-12 Plant Case, J. M. Griffin, J. D. Hibbs, R. F. Jasny, G. R. Vanstrum, P. R. Zerby, C. D. 